\title{
Assessment of the GBR Source Catchments model to estimate fine-sediment streambank erosion and export
}

\author{
$\underline{\text { R. Baheerathan }}^{\text {a }}$, R. Ellis ${ }^{\mathrm{b}}$, B. Fentie ${ }^{\mathrm{b}}$, G.L. McCloskey ${ }^{\mathrm{a}}$ and D. Waters ${ }^{\mathrm{a}}$ \\ ${ }^{a}$ Department of Natural Resources and Mines, Queensland. \\ ${ }^{b}$ Department of Science, Information Technology and Innovation, Queensland. \\ Email: Ramanan.Baheerathan@,dnrm.qld.gov.au
}

\begin{abstract}
Streambank erosion presents a serious threat to a range of aquatic ecosystems, from freshwater to marine, including the Great Barrier Reef (GBR), Australia. Therefore, it is imperative to continue to assess and improve techniques to estimate the magnitude and spatial distribution of streambank erosion across the GBR catchments to assist with prioritising where remediation should be undertaken and to evaluate the efficacy of strategies proposed to prevent bank erosion.
\end{abstract}

The GBR Source Catchments modelling framework via the Dynamic SedNet (DS) plugin, provides a means of predicting fine-sediment streambank erosion at a user specified stream reach scale. DS calculates a mean annual rate of streambank erosion as a function of various hydro-geomorphic characteristics of streams. The mean annual streambank erosion is then disaggregated as a function of the daily flow and distributed over the model run period. The daily streambank erosion load is then apportioned to fine and coarse sediment according to the clay and silt proportion. Where appropriate data is available to parameterise the model, DS can also be used to assess the efficacy of strategies proposed to prevent streambank erosion. Moreover, in addition to streambank erosion, DS estimates total fine-sediment export to the GBR by simulating fine-sediment supplies from other major sources (e.g. hillslope and gully erosion) and losses at various sinks (e.g. floodplains and dams).

In this study, DS modelled fine-sediment streambank erosion along the O'Connell River $(\sim 45 \mathrm{~km})$, lower Burnett River main-stem $(\sim 300 \mathrm{~km})$, East and West Normanby Rivers $(\sim 42 \mathrm{~km}$ and $39 \mathrm{~km})$ and Laura River $(\sim 29 \mathrm{~km})$ were compared against published estimates. DS modelled total fine-sediment exports to the GBR from the O'Connell and Burnett basins, and Normanby River were also compared against estimates from the Great Barrier Reef Catchment Loads Monitoring Program (GBRCLMP) to ensure modelled total fine-sediment exports were sensible.

The comparison between DS modelled fine-sediment streambank erosion along the O'Connell River between 2010 and 2014 against that estimated by the O'Connell River stability assessment (ORSA) was encouraging. The DS estimate was only $8 \%$ greater than the ORSA estimate. Moreover, DS modelled total fine-sediment export from the O'Connell basin to the GBR was only $2 \%$ lower than the GBRCLMP estimate.

The Burnett River channel and bank stability assessment (BRCBSA) estimate of fine-sediment streambank erosion along the lower Burnett River main-stem was approximately six times greater than that modelled by the DS between 2009 and 2013. The Normanby basin sediment budget assessment (NBSBA) estimates of average annual fine-sediment streambank erosion along the East and West Normanby, and Laura Rivers were approximately 75, 50, and 55 times greater than that estimated by DS. Despite these discrepancies, it is encouraging to note that DS modelled total fine-sediment loads exported from the Burnett basin and the Normanby River showed good agreement with the GBRCLMP estimates. Modelled total fine-sediment exports from the Burnett basin and Normanby River were only 3\% greater and 6\% lower than the GBRCLMP estimates respectively.

This work demonstrates that the GBR Source Catchments modelling framework via the DS plugin can be used for approximating total fine-sediment loads being exported to the GBR. Despite the ability of DS to estimate fine-sediment streambank erosion along the O'Connell River, further investigations are required into the discrepancies between DS modelled and published estimates of fine-sediment streambank erosion by the BRCBSA in the Burnett, and by the NBSBA in the Normanby, and Laura Rivers.

Keywords: Streambank erosion, GBR Source Catchments Modelling, Dynamic SedNet 
Baheerathan et al., Assessment of the GBR Source Catchments model to estimate fine-sediment streambank erosion and export

\section{INTRODUCTION}

Streambank erosion presents a serious threat to a range of aquatic ecosystems, from freshwater to marine, including the Great Barrier Reef(GBR), Australia. By delivering substantial amounts of sediments, streambank erosion can impact such ecosystems by reducing light availability, smothering corals, and associated losses of flora and fauna (Bartley et al., 2014 and GBRMPA, 2016). Consequently, water quality targets have been set as part of the Reef Water Quality Protection Plan (Reef Plan) to reduce anthropogenic fine-sediment loads leaving the GBR catchments. Therefore, it is imperative to continue to assess and improve techniques to estimate the magnitude and spatial distribution of fine-sediment streambank erosion across the GBR catchments to assist with prioritising where remediation should be undertaken and to evaluate the efficacy of strategies proposed to prevent streambank erosion.

A range of techniques have been used to estimate streambank erosion across the GBR namely, aerial photography, Light Detection and Ranging (LiDAR), end-of-system (EOS) water quality monitoring, Bank Stability and Toe Erosion Modelling (BSTEM) and Dynamic SedNet modelling (Alluvium, 2014, Brooks et al., 2013, Cardno ENTRIX, 2014, and McCloskey et al., 2017, and Turner et al., 2013). Each method has advantages and disadvantages. For example, aerial photos are used to identify where major streambank erosion has occurred, but has limited use for estimating quantities of sediment supply. Conversely, repeat LiDAR surveys can be used to quantify sediment supply due to streambank erosion. However, acquisition of high resolution LiDAR for accurate assessments is expensive and only available in limited areas at this point. This is problematic when assessments are required across many streams. End of system (EOS) monitoring provides a useful estimate of the total sediment loads exported for a given space and time. However, this approach does not provide adequate information on differentiating sediment supplies from sources (e.g. streambank, hillslope or gully erosion) or sediment losses at sinks (e.g. deposition in dams and on floodplains). The ability of BSTEM to simulate hydraulic and geotechnical processes that influence the streambank retreat and erosion, makes it a useful tool to simulate bank-stability conditions and design streambank-stabilisation measures (Brooks et al., 2013). However, using BSTEM results to spatially interpolate or extrapolate bank-derived volumes of sediment from individual sites to entire stream lengths should be undertaken with caution. This approach may under or overestimate sediment supply from catchment or basin scale streambank erosion, depending on the spatial variability of bank erosion (Cardno ENTRIX, 2014 and Brooks et al., 2013). The GBR Source Catchments modelling framework via the Dynamic SedNet plugin, provides a means of predicting streambank erosion at a user specified stream reach scale by incorporating various hydro-geomorphic characteristics of streams. The confidence in erosion estimates, like all modelling, will be highly dependent on the accuracy of input datasets and it is limited to stream reach scale investigations. Where appropriate data is available to parameterise the model, the model can also be used to assess efficacy of strategies proposed to prevent streambank erosion. Moreover, in addition to streambank erosion, Dynamic SedNet estimates total fine-sediment export to the GBR by simulating fine-sediment supplies from other major sources (e.g. hillslope and gully erosion) and losses at various sinks (e.g. floodplains and dams).

\section{METHODS}

\subsection{Overview}

As part of the Paddock to Reef program, hydrology and water quality models of all six natural resource management (NRM) regions of the GBR catchments were developed on GBR Source Catchments modelling platform, to report on progress towards the Reef Plan water quality targets (McCloskey et al., 2017).

Dynamic SedNet (DS), a GBR Source Catchments 'plug-in' developed to assist the GBR catchment modelling program, was used to simulate fine-sediment supply from major sources and losses at various sinks at a finer temporal resolution than the original average annual SedNet model (Ellis, 2017), including:

- streambank, hillslope, and gully erosion;

- in-stream and floodplain deposition and remobilisation; and

- storage trapping.

The 'bank erosion' component of the 'In Stream Processing Model' available in the DS plugin estimates sediment supply due to streambank erosion in regional scale river networks of catchments ranging from 3,000 to $1,000,000 \mathrm{~km}^{2}$ (Ellis, 2017). The bank erosion model calculates a mean annual rate of streambank erosion as a function of various hydro-geomorphic characteristics of streams, including, for example, river bed slope, bank height, stream length, bank full flow, riparian vegetation extent and streambank erodibility. The mean annual streambank erosion is then disaggregated as a function of the daily flow and distributed over the model 
Baheerathan et al., Assessment of the GBR Source Catchments model to estimate fine-sediment streambank erosion and export

run period. The daily streambank erosion load is then apportioned to fine and coarse sediment according to the clay and silt proportion.

In this study, we compare DS modelled fine-sediment streambank erosion (in Report Card ${ }^{1}$ 2016) against estimates of streambank erosion investigations undertaken in the O'Connell, Burnett, and Normanby River systems (Alluvium, 2014, Cardno ENTRIX, 2014 and Brooks et al., 2013) as described below. DS modelled total fine-sediment exports from the O'Connell and Burnett basins and, Normanby River to the GBR were also compared against the GBRCLMP estimates to ensure modelled total fine-sediment exports were sensible.

\subsection{O'Connell River Stability Assessment}

The O'Connell River stability assessment (ORSA) was undertaken to estimate sediment supply due to streambank erosion from major erosion sites along five different reaches in the O'Connell River (Alluvium 2014). The volume of sediment eroded between 2010 and 2014 was estimated using digital elevation models (DEMs) derived from LiDAR data sets acquired in those years. From the 2010 and 2014 DEMs, a DEM of Difference (DOD) was developed to estimate volumes of sediment eroded at a specific location at different points in time.

In order to compare against the DS modelled fine-sediment streambank erosion, the ORSA derived volumes of total sediment supply along the reaches were multiplied by the clay and silt proportion applied at the same location in the DS catchment model.

An initial comparison between fine-sediment supplies modelled as part of a previous report card (RC 2015) against that estimated by the ORSA revealed that the DS estimated less overall fine-sediment streambank erosion along the O'Connell River by approximately $26 \%$. Consequently, the 'bank erosion coefficient' of the latest DS catchment model

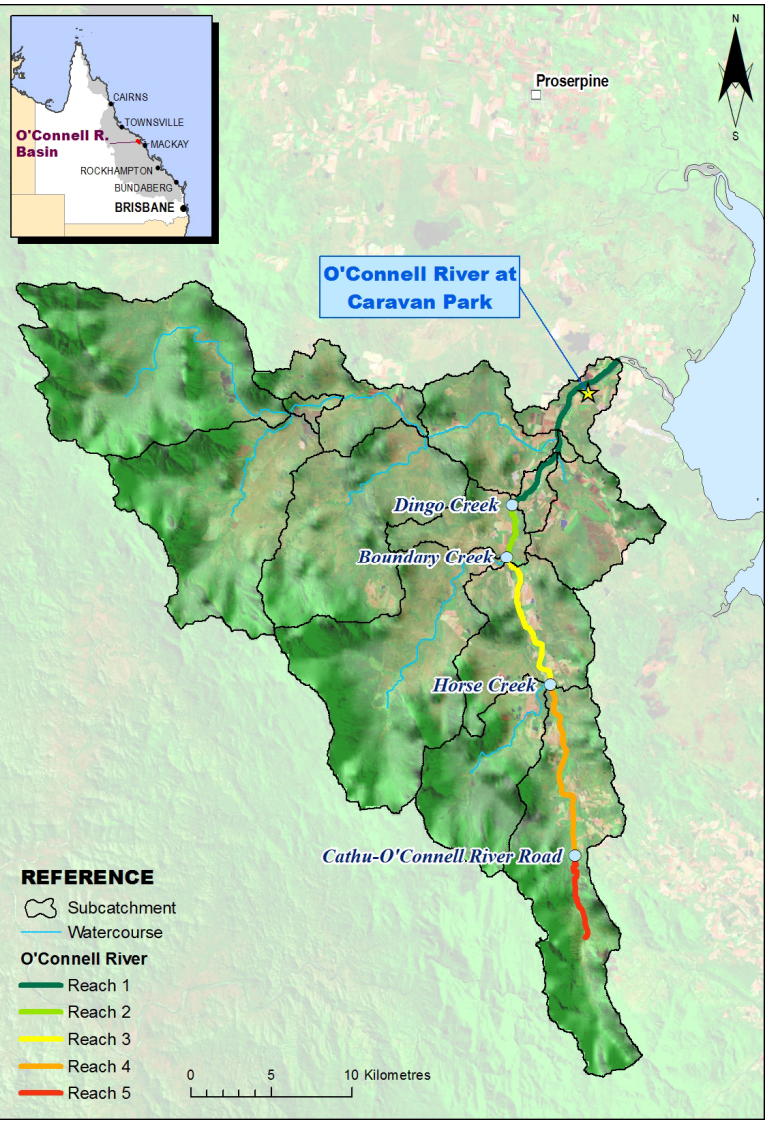

Figure 1. The five reaches along the O'Connell River.

(in RC 2016) was calibrated using the ORSA estimates for fine-sediment streambank erosion supply in the most upper two reaches; reaches 4 and 5 (Figure 1). Here the ORSA estimated total fine-sediment supply from reaches 4 and 5 were compared against that modelled in a single sub-catchment because the model did not have adequate resolution to assess them separately. The latest DS catchment model was then validated by comparing modelled fine-sediment streambank erosion in reaches 1, 2, and 3 against that estimated by the ORSA. The DS modelled average annual total fine-sediment export was also compared against GBRCLMP estimates in the O’Connell River at Caravan Park EOS site.

\subsection{Channel and Bank Stability of Selected Reaches of the Burnett River System}

The Burnett River channel and bank stability assessment (BRCBSA) was undertaken along the lower $300 \mathrm{~km}$ of the Burnett River main-stem to estimate the volume of sediment eroded from the banks due to the severe flooding experienced in early 2011 and 2013 (Cardno ENTRIX 2014). In the BRCBSA, the amount of lateral retreat of banks was determined over adjacent 2-km reaches using an analysis of the 2010 pre-flood and 2013 post-flood, aerial photography. The lateral retreat amounts were then combined with the "percent reach failing" data obtained from Rapid Geomorphic Assessments (RGAs) and bank height data, to estimate eroded sediment volume along the entire lower Burnett River main-stem. Site investigations were also carried out to estimate unit-erosion rates using BSTEM modelling at priority sites selected for bank stabilization and erosion

\footnotetext{
${ }^{1}$ Report Card measures progress towards Reef Plan's goals and targets.
} 
Baheerathan et al., Assessment of the GBR Source Catchments model to estimate fine-sediment streambank erosion and export

mitigation. BSTEM results were then used to estimate streambank erosion for the entire lower Burnet River main-stem by interpolating the modelled site specific erosion rates to adjacent reaches and then summing them for the entire river.

In order to compare against the DS modelled fine-sediment streambank erosion along the lower Burnett River main-stem (Figure 2), the BSTEM derived volume of total sediment supply between 2009 and 2013 was multiplied by the sediment bulk density of 1.5 $\mathrm{t} / \mathrm{m}^{3}$ as used in the DS catchment model and fine-sediment percentage of $54 \%$ derived by the BRCBSA. The DS modelled total finesediment export between 2009 and 2013 was also compared against GBRCLMP estimates in the Burnett River at Ben Anderson Barrage EOS site to ensure modelled total finesediment export was sensible.

\subsection{An Empirically-based Sediment Budget for the Normanby Basin}

The Normanby basin sediment budget assessment (NBSBA) estimated finesediment streambank erosion along the East and West Normanby and Laura Rivers and Crocodile Creek (Brooks et al., 2013). The estimated eroded volumes from the BSTEM runs were combined with the 'percent reach failing' data obtained from a video recorded along the study reach during helicopter reconnaissance, and bank height data provided from available LiDAR and through modeling, to extrapolate eroded sediment volumes throughout the study watersheds. Particle size data were then applied to be able to distinguish the fraction of the total eroded volume that was fine-sediment.

The average annual fine-sediment streambank erosion supply estimated by the NBSBA (between 1971 and 2011) along the East and West Normanby Rivers and Laura River (Figure 3) were compared against that modelled by DS between 1986 and 2014. The catchment model did not have adequate resolution to compare NBSBA estimated fine-sediment streambank erosion along Crocodile Creek. The DS modelled average annual total fine-sediment export between 2006 and 2014 was also compared against GBRCLMP estimates in the Normanby River at Kalpowar monitoring site.

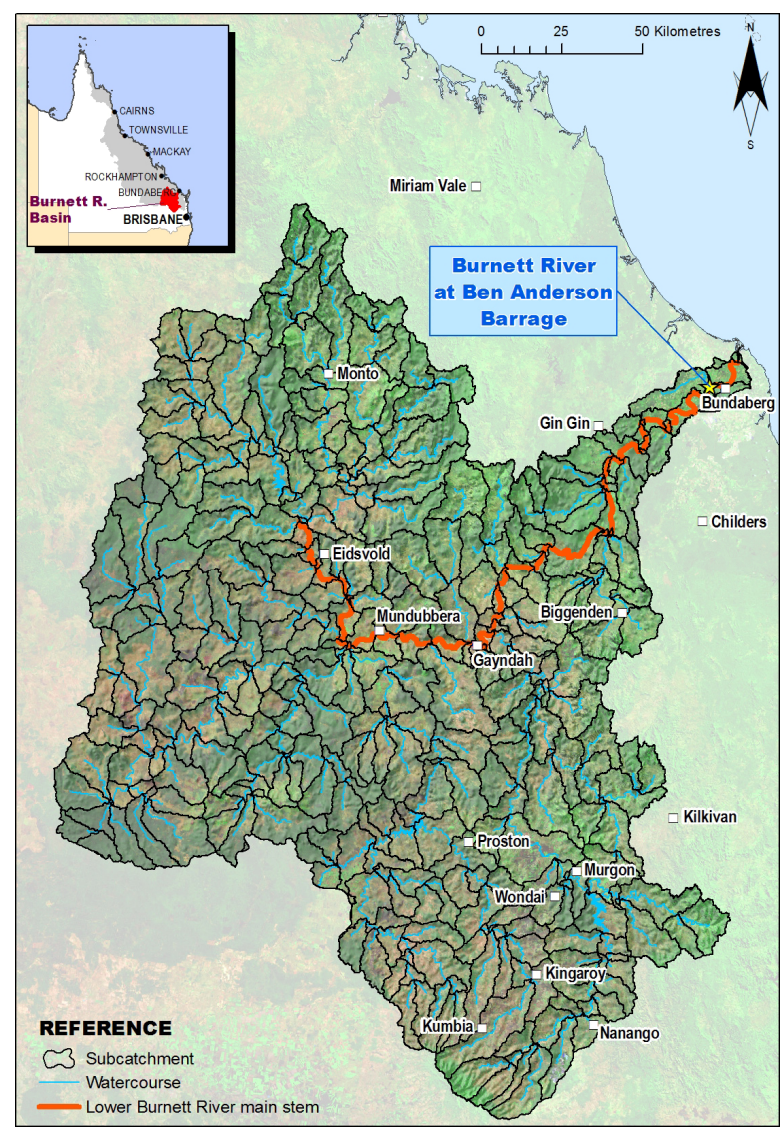

Figure 2. The lower Burnett River main-stem.

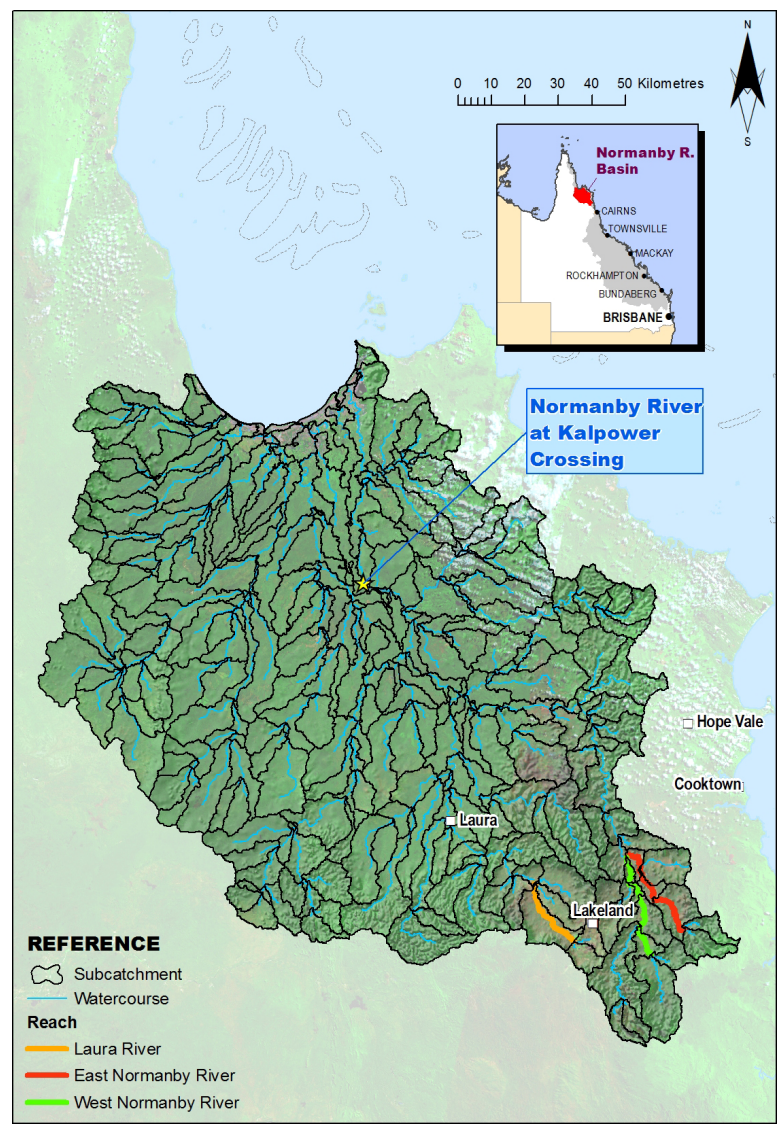

Figure 3. The East and West Normanby and Laura Rivers. 
Baheerathan et al., Assessment of the GBR Source Catchments model to estimate fine-sediment streambank erosion and export

\section{RESULTS}

Comparisons between DS modelled fine-sediment streambank erosion along the O'Connell River, lower Burnett River main-stem, East and West Normanby Rivers, and Laura River against that estimated by other investigations are compared. DS modelled total fine-sediment exports from the O'Connell and Burnett basins and Normanby River to the GBR are also compared against the corresponding GBRCLMP estimates.

\subsection{O'Connell River - Mackay Whitsunday Region}

Table 1 compares DS modelled fine-sediment streambank erosion along the O'Connell River and its reaches between 2010 and 2014 against that calculated from the ORSA estimates.

Table 1. Fine-sediment streambank erosion along the O’Connell River.

\begin{tabular}{|c|c|c|}
\hline \multirow{2}{*}{} & \multicolumn{2}{|c|}{ Fine-sediment streambank erosion (m3) } \\
\cline { 2 - 3 } & DS & ORSA \\
\hline Reach - 1 & 83,953 & 80,410 \\
\hline Reach - 2 & 2,400 & 6,460 \\
\hline Reach - 3 & 20,193 & 21,000 \\
\hline Reach - 4 \& 5 & 30,729 & 27,360 \\
\hline Overall O'Connell River & 141,334 & 131,170 \\
\hline
\end{tabular}

\subsection{Lower Burnett River - Burnett Mary Region}

DS modelled fine-sediment streambank erosion along the lower Burnett River main-stem between 2009 and 2013 was 3 million tonnes, whereas that calculated from the BRCBSA estimates was 20 million tonnes.

\subsection{East and West Normanby Rivers and Laura River- Cape York Region}

Table 2 compares DS modelled average annual fine-sediment streambank erosion along the East and West Normanby Rivers and Laura River between 1986 and 2014 against NBSBA estimates between 1971 and 2011.

Table 2. Average annual fine-sediment streambank erosion in Normanby baisn.

\begin{tabular}{|c|c|c|}
\hline \multirow{2}{*}{} & \multicolumn{2}{|c|}{ Fine-sediment streambank erosion supply (tonnes per year) } \\
\cline { 2 - 3 } & DS & NBSBA \\
\hline East Normanby River & 348 & 26,000 \\
\hline West Normanby River & 1,150 & 57,700 \\
\hline Laura River & 237 & 13,100 \\
\hline
\end{tabular}

\subsection{Load Monitoring and Modelled load estimates}

DS modelled average annual total fine-sediment loads exported from the O'Connell basin and Normanby River to the GBR against the corresponding GBRCLMP estimates are compared in Table 3 . Table 3 also compares DS modelled total fine-sediment loads exported from the Burnett basin to the GBR against GBRCLMP estimate between 20009 and 2013.

Table 3. Fine-sediment loads exported from the O'Connell and Burnett basins, and Normanby River.

\begin{tabular}{|c|c|c|}
\hline & DS & GBRCLMP \\
\hline $\begin{array}{c}\text { Average annual fine-sediment export from the O'Connell } \\
\text { basin between 2007 to 2009 and 2013 (kilo tonnes per year) }\end{array}$ & 100 & 102 \\
\hline $\begin{array}{c}\text { Total fine-sediment export from the Burnett basin between } \\
2009 \text { and 2013 (million tonnes) }\end{array}$ & 6.7 & 6.5 \\
\hline $\begin{array}{c}\text { Average annual fine-sediment export from the Normanby } \\
\text { basin between 2006 and 2014 (kilo tonnes per year) }\end{array}$ & 134 & 142 \\
\hline
\end{tabular}


Baheerathan et al., Assessment of the GBR Source Catchments model to estimate fine-sediment streambank erosion and export

\section{DISCUSSION AND CONCLUSIONS}

In this study, DS modelled fine-sediment streambank erosion along the O'Connell River, lower Burnett River main-stem, East and West Normanby Rivers, and Laura River were compared against that estimated by other investigations. DS modelled total fine-sediment exports from the O'Connell and Burnett basins, and Normanby River to the GBR were also compared against the GBRCLMP estimates to ensure modelled total fine-sediment loads were sensible.

The comparison between DS modelled fine-sediment streambank erosion along the O'Connell River between 2010 and 2014 against that estimated by the O'Connell River stability assessment was encouraging. The DS estimate was only $8 \%$ greater than the ORSA estimate. Moreover, DS modelled total fine-sediment export from the O'Connell basin to the GBR was only 2\% lower than the GBRCLMP estimate at the Caravan Park EOS site. Total fine-sediment streambank erosion is likely to have been higher than the ORSA estimate because the ORSA did not include sediment release from minor erosion sites, due to uncertainties associated with identifying minor streambank erosion sites in the DOD developed using the repeat LiDAR datasets.

The Burnett River channel and bank stability assessment estimated fine-sediment streambank erosion between 2009 and 2013 was approximately six times larger than that estimated by the DS catchment model. This is despite the fact that the BRCBSA did not include fine-sediment contributions from other sources, such as hillslopes, gullies, and tributaries. The BRCBSA estimate of fine-sediment streambank erosion was also two times larger than the GBRCLMP load estimate for fine-sediment exported from the entire Burnett basin. This indicates that about two-thirds of the fine-sediment streambank erosion estimated by the BRCBSA would need to be deposited on low-bank surfaces, beds, bars, floodplains, and behind dams to match the total fine-sediment export estimated by the GBRCLMP. It can be assumed, however, that most of the fine-grained materials (i.e. clay and silt) are exported to the GBR as they are unlikely to be deposited during the severe flood conditions observed in early 2010 and 2013. DS modelled total fine-sediment export was within 3\% of the GBRCLMP Burnett basin export load. Despite the differences in fine-sediment streambank erosion estimates, it is encouraging that both DS and BRCBSA suggest that streambank erosion dominates the sediment supply in the Burnett basin.

The Normanby basin sediment budget assessment estimated greater average annual fine-sediment streambank erosion along the East and West Normanby Rivers and Laura River by approximately 75, 50, and 55 times than that estimated by the DS catchment model. One potential reason for the higher estimates from the NBSBA method is the different periods over which the two estimates were derived. The DS estimates were between 1986 and 2014 whilst the NBSBA estimate was for 1971 to 2011. A number of large flow events that occurred between 1971 and 1985 were outside the catchment model run period and could have potentially generated additional streambank erosion. Future DS catchment modelling may look to extend the modelling period to investigate this issue. While the accuracy of the 'percent reach failing' estimated using the RGA analysis is unknown, spatially interpolating or extrapolating BSTEM derived unit-streambank erosion rates at a few priority sites to estimate streambank erosion for the entire river systems may also be contributing to the large discrepancy between the two estimates.

Despite the aforementioned discrepancies in fine-sediment streambank erosion estimates, it is encouraging to note that DS modelled total fine-sediment loads exported from the Burnett basin at the Ben Anderson Barrage EOS site and the Kalpowar site on the Normanby River were within 6\% of the GBRCLMP estimates.

The observed close match between the DS modelled and ORSA estimates of fine-sediment streambank erosion along the O'Connell River may be due to the fact that the DS catchment model of the O'Connell River system was calibrated for the most upper two reaches $(\sim 15 \mathrm{~km}$ out of $45 \mathrm{~km})$ using the ORSA estimate. Such calibration attempts were not made in DS models of the Burnett, Normanby, and Laura Rivers due to the large discrepancies observed between the DS modelled estimates and published estimates.

This work demonstrates that the GBR Source Catchments modelling framework via the DS plugin can be used for approximating total fine-sediment loads being exported to the GBR. Despite the ability of DS to estimate fine-sediment streambank erosion along the O'Connell River, further investigations are required into the discrepancies between DS modelled and the other estimates of fine-sediment streambank erosion in the Burnett, Normanby, and Laura Rivers.

\section{ACKNOWLEDGMENTS}

Authors acknowledge the assistance by David Burton of the Department of Natural Resources of Mines to produce figures presented in this paper. 
Baheerathan et al., Assessment of the GBR Source Catchments model to estimate fine-sediment streambank erosion and export

\section{REFERENCES}

Alluvium. (2014). O’Connell River Stability Assessment.

Bartley, R., Bainbridge, Z.T., Lewis, S.E., Kroon, F.J., Wilkinson, S.N., Brodie, J.E., and Silburne, D.M. (2014). Relating sediment impacts on coral reefs to watershed sources, processes and management: a review. Sci Total Environ 468-469:1138-1153.

Brooks, A., Spencer, J., Olley, J., Pietsch, T., Borombovits, D., Curwen, G., Shellberg, J., Howley, C., Gleeson, A., Simon, A., Bankhead, N., Klimetz, D., Eslami-Endargoli, L., and Bourgeault, A. (2013). An Empirically-based Sediment Budget for the Normanby Basin. Appendix 09: Validation and Calibration of BSTEM for select sites on the East Normanby River.

Cardno ENTRIX. (2014). Channel and Bank Stability of Selected Reaches of the Burnett River System, QLD, Australia.

Ellis, R.J. (2017). Dynamic SedNet Component Model Reference Guide: Update 2017, Concepts and algorithms used in Source Catchments customisation plugin for Great Barrier Reef catchment modelling, Department of Science, Information Technology and Innovation, Bundaberg, Queensland.

GBRMPA (2016). "Great Barrier Reef Marine Park Authority." from www.gbrmpa.gov.au.

McCloskey, G.L., Waters. D., Baheerathan, R., Darr, S., Dougall, C., Ellis, R., Fentie, B., and Hateley, L. (2017). Modelling pollutant load changes due to improved management practices in the Great Barrier Reef catchments: updated methodology and results - Technical Report for Reef Report Cards 2015, Queensland Department of Natural Resources and Mines, Brisbane, Queensland.

Turner. R., Huggins. R., Wallace. R., Smith. R., Vardy. S., and Warne M. S. J. (2013). Total suspended solids, nutrient and pesticide loads (2010-2011) for rivers that discharge to the Great Barrier Reef. Great Barrier Reef Catchment Loads Monitoring 2010 -2011. Department of Science, Information Technology, Innovation, Brisbane. 